\title{
An Overview of Climate Change And Its Impact on Agriculture: a Review From Least Developing Country, Nepal
}

\author{
Rahul Karki ${ }^{1}$, Anup Gurung, ${ }^{2, *}$ \\ ${ }^{1}$ ForestAction, Satdobato, Kathmandu, Nepal \\ ${ }^{2}$ Department of Biological Environment, Kangwon National University, Gangwon-do, Chuncheon-si, South Korea
}

\begin{abstract}
Climate is an important factor for agricultural production. However, in recent years consistent warming and rise in global temperature has resulted in visible impacts on the agriculture across the world. Nepal is not an exceptional case, where rising temperature has already affected the country's agricultural production thereby affecting the food security and agrarian communities. It is expected that the level of vulnerability will be higher in high altitude as compared to the lower altitude. In addition, majority of the population are subsistence farmer in rural parts of Nepal and has low land holding capacity. Nepal is one of the least developed countries in the world with low per capita income, and thus the country's ability to adapt to the extreme climatic events has direct implications in its strategies on agriculture sector development. However, Nepal still lack strong scientific data about the cases of climate change and due to varied geographical setting, sufficient meteorological data cannot be easily obtained from remote parts of the country. This review tries to explore the current status of vulnerability to the climate change in Nepal. In Nepal, more than $80 \%$ of the people heavily rely on agriculture for their subsistence and thus, climate change will bring expectedly negative response to the agricultural sector in the country.
\end{abstract}

Keywords Agriculture, adaptive capacity, climate change, developing countries, agrarian communities

\section{Introduction}

Climate is an essential factor that has direct effects on agricultural production[1-3]. The increased impacts of climate change put the agricultural sector at the central point of discussion globally since the sector contributes to global climate change as well as can be affected by the changing climate[2-5]. The impacts of climate change on agriculture production are both positive as well as negative, however, the impacts will differ globally[2, 5].

Developing countries are more vulnerable to climate change since majority of the populations depend on agriculture and lacks technical and financial capability to respond to increased variability $[1,6,7]$. In addition, the agricultural sector is not only vulnerable to climate change but also has been stressed with the chronic problems of low returns from agricultural exports in developing countries $[4,8,9]$. In recent years, climate change has been a topic of discussion in Nepal due to its increasing stress on water resources and other climate-sensitive resources thereby

* Corresponding author:

anupknu@gmail.com (Anup Gurung)

Published online at http://journal.sapub.org/ije

Copyright (C) 2012 Scientific \& Academic Publishing. All Rights Reserved affecting agricultural production, food security and livelihood[3,5,7,10].

Although Nepal is potentially much vulnerable to the impacts of climate change, there is limited data pertaining to climate change and agriculture. It is understood that the climate change and climate policy will have significant impacts on agriculture productions and livelihood of agrarian communities[1,11]. Table 1 shows the ecological zones of Nepal.

Table 1. Geographical features of Nepal [12-14]

\begin{tabular}{cccc}
\hline Parameters & Mountains & Hills & Terai \\
\hline Climate & Tundra & Temperate & Sub-tropical \\
Temperature* & $<3^{\circ} \mathrm{C}-10^{\circ} \mathrm{C}$ & $10^{\circ} \mathrm{C}-20^{\circ} \mathrm{C}$ & $20^{\circ} \mathrm{C}-25^{\circ} \mathrm{C}$ \\
Precipitation** & Snow $/ 150-200$ & $275-2,300$ & $1,100-3,000$ \\
\% of total area & 35 & 42 & 23 \\
Cultivated area & 0.3 & 46.1 & 51.6 \\
\hline
\end{tabular}

*Mean annual temperature, **Average annual precipitation (mm)

Nepal is one of the least developed countries in the world with rich ethnic diversity and has varied geographical setting where agriculture has played fundamental role in maintaining fiscal and socio-economic stability[7,11,15]. Climate change is expected to affect the agricultural production, thereby affecting the livelihood and food security in poor rural parts of developing countries[1,2,4]. Thus, this review 
was carried out to know about the ongoing climate change and to predict possible changes that are likely to affect the agrarian communities of Nepal. This review also discusses about the adaptation and mitigation of climate change in relation to agriculture sector in Nepal.

\section{Climate Change in Nepal}

Nepal is a small landlocked country with a total area of $147,181 \mathrm{~km}^{2}$ and located in the heart of Himalayas[16]. The geographical structure of Nepal resembles a rectangular shape with three main ecological zones running horizontally as continuous belts, namely, plains, hills and mountains $[7,17,18]$. The elevation of the country varies from $100 \mathrm{~m}$ in plain to $8,850 \mathrm{~m}$ in the Himalayas[19]. Due to such sharp altitudinal variation, Nepal is vulnerable to various types of natural disasters such as landslide, slope failure, soil erosion, landmass movement, and flood[3,7,17]. Table 2 summarizes information about the likely changes to the temperature, precipitation and runoff for Nepal due to climate change.

Table 2. Anticipated climate change impacts in Nepal [20-23]

\begin{tabular}{cc}
\hline Parameter & Remarks \\
\hline \multirow{3}{*}{ Temperature } & Significant and persistent rise in temperature \\
\cline { 2 - 2 } & 0.5 to $2.0^{\circ} \mathrm{C}$ by 2030 \\
1.3 to $3.8^{\circ} \mathrm{C}$ by 2060 \\
1.8 to $5.8^{\circ} \mathrm{C}$ by 2090 \\
Changes in mean annual rainfall \\
\cline { 2 - 2 } Precipitation & -34 to $+22 \%$ by the year 2030 \\
& -36 to $+67 \%$ by the year 2060 \\
& -43 to $+89 \%$ by the year 2090 \\
Changes in monsoon rainfall \\
\cline { 2 - 2 } \\
Runoff & -14 to $40 \%$ by the year 2030 \\
& -40 to $+143 \%$ by the year 2060 \\
& -52 to $+135 \%$ by the year 2090 \\
\cline { 2 - 2 } & Higher downstream flows in the short term, but \\
lower downstream flows in the long term due to \\
retreating glaciers and snowmelt \\
Shift from snow to rain in winter season \\
Increased natural disasters such as flash floods, \\
mass movement, droughts and GLOF
\end{tabular}

In recent years, climate change has further amplified the situation by affecting the water resources, which ultimately add stress to the agricultural production[3,5,10,17]. A review of literature revealed that Nepal's climate continued to rise in maximum temperature at an annual rate between $0.04^{\circ} \mathrm{C}$ and $0.08^{\circ} \mathrm{C}[10,21,24]$. The continued rise in temperature and increase in rainfall have significant impacts on agricultural production and livelihood of agrarian communities, especially in subsistence farming $[10,17,25]$. The changes in the climatic conditions have brought potentially significant new challenges, most critical are likely to be impact on local natural resources, biodiversity and environment, and leads to changes in biological, geophysical and socioeconomic elements $[1,3,26]$.

For Nepal, it is predicted that there will be a significant and consistent increase in temperature and annual precipitation in the coming years-2030, 2060 and 2090[20-23]. Ap- proximately $80 \%$ of the territory is occupied by hills and mountains, and consistent rise in temperature will accelerate the process of avalanche and glacier retreat in such regions [16]. Therefore, the ongoing climatic change and changes those are anticipated to occur in the coming years are likely to affect water resources including glacial fluctuation, hydrological regime, Glacier Lake Outburst Flood (GLOF), decline in agricultural production and food security, and biodiversity[3,16,17]..

In Nepal, the warming rate is significantly higher than the global average warming rate, and the warming rate is found to be more pronounced in the Himalayas[16]. This poses direct impact on the plains during monsoon season when heavy rainfall coincides with the glacier and snowmelt from the mountains[7,16,17,21]. In addition, the impact of climate change is increasing steadily by resulting uncertainties and climate-induced extreme events[7,21]. However, Nepal has low adaptive capacity to respond to the variability occurs due to climate change[7]. Moreover, the assessment and predictions of climate change are mostly based on literature review and some scattered information, which were not so reliable [27]. Nevertheless, the country is severely threatened by the expected impacts of climate change especially affecting agricultural production, biodiversity and livelihood of agrarian communities[3,5,11].

\section{Impacts of Climate Change on Agriculture in Nepal}

Nepal is one of the least developed country in the world with low GDP of US\$562[28]. It is estimated that approximately $25 \%$ of the populations live below the poverty line as of US\$ 1.25 a day[19]. Agriculture is the dominant sector in Nepal[7,15]. It accounts more than $75 \%$ of human resource involvement and contributes to $35 \%$ of GDP (2011) [15,18, 29,30]. Agriculture sector has played fundamental role in human welfare especially in rural Nepal, where people heavily depend on agricultural exports for their fiscal and socio-political stability[4,9,15,19].

However, the contribution of agricultural sector to the national economy is challenged by its vulnerability to climate change[5,11]. In recent years, extreme climatic conditions such as persistent rise in mean annual temperature and increase in precipitation have almost adverse impacts of various elements of agricultural production system[10,11]. In addition, Nepal is experiencing various natural disasters such as flash floods, hailstones, landslides, mass movement, soil erosion, and avalanche, there by affecting the agriculture systems $[3,7,10,16]$. The level of vulnerability, however, will be dependent on both socioeconomic and environmental factors[2,5]. In Nepal, approximately $85 \%$ of the population live in rural areas, and thus, concern has been expressed by many researchers and organizations that climate change will undermine the rural economy who typically depend on climate-sensitive natural resources[7,29,31]. 


\subsection{Pattern of Agriculture in Nepal}

The most vulnerable groups are the poor, marginalized and underprivileged population in rural parts of Nepal, whose livelihoods primarily depend on agriculture[7,31]. Although Nepal is predominantly an agricultural country, approximately $78 \%$ of the farmers are harvesting agricultural products mainly for household consumption[32]. In addition, nearly $60 \%$ of farmers cannot meet their own food needs, especially in higher mountainous areas, where household can meet their food requirements for 3- 8 months per year[30,32]. In such areas, the majority of farmers rely on rain fed crops and follow labour intensive traditional methods for farming $[9,10]$.

Table 3. Categorization of households based on the size of land ownership as of 2001 [33]

\begin{tabular}{ccc}
\hline Household category & $\begin{array}{c}\text { Total household } \\
\text { number }\end{array}$ & $\begin{array}{c}\text { Size of land } \\
\text { ownership (ha) }\end{array}$ \\
\hline Landless farmers & 287100 & $0-0.1$ \\
Marginal farmers & 670000 & $0.1-0.3$ \\
Small farmers & 648000 & $0.3-0.5$ \\
Medium farmers & 1131560 & $0.5-3.0$ \\
Large farmers & 93700 & $3.0-10.0$ \\
Extra large farmers & 3800 & $>10.0$ \\
\hline
\end{tabular}

Approximately $17 \%$ of the total land area of Nepal is agricultural land[14,15,33,34]. Due to continuous fragmentation of land, the land holding capacity per household across Nepal is found to be relatively low; estimated average size of parcel is to be less than 1.0 ha[14]. According to the estimation carried out by Agricultural Census 2001, there were a total of 4,253,222 households in Nepal in which 3,364,100 were farming households (Table 3)[14,33].

Although agriculture sector remains the major source of income and employment opportunities in Nepal, agriculture is mainly based on low-value cereals and subsistence production[9,15,32]. Despite of getting special attention from government and other donor agencies in term of formulation and implementation of appropriate policies, the development of agriculture sector is still implausible in the country[15]. Furthermore, due to lack of investment capacity and infrastructure as well as lack of market opportunities for agricultural products, majority of the poor peasants are still adopting traditional technology in their production system $[9,35]$. It is estimated that hardly $13 \%$ of the agricultural products are traded in the market[32].

On the other hand, regional variation in the distribution of agricultural land is substantial in Nepal[33,34]. Although the plain covers only $17 \%$ of the total land area, it comprises $49 \%$ of the total agricultural land[13,18,19,36]. Similarly, the hills and the mountains cover 63 and $20 \%$ of the total land area accounting for 40 and $11 \%$ of agricultural land, respectively $[13,36]$. In other words, the highest availability of agriculture land in plain is 0.944 ha, followed by 0.655 and 0.633 ha, respectively in hills and mountains[14,33,34,36]. There is a great variation in the land ownership among rural populations and majority of the populations do not have enough land to live on[37]. Overall, approximately 2.3 Nepalese are landless, and primarily rely on shared cropping and tenancy for their livelihood[37].

\subsection{Impact of Climate Change on Cereal Production}

Agriculture sector plays fundamental role in the Nepalese economy and contributes about $80 \%$ of the exports and one-third of the county's GDP[15]. Cereal crops including rice, wheat, maize, millet, barely and buckwheat are the mainstay of Nepal's agriculture[15]. However, Nepal is much vulnerable to climate change due to weather variability associated with rising temperature and changing pattern of precipitation[11,24]. Rice is the prime food crop of the country which could face risk due to changes in the reliability of stream flows, a more intense and potentially erratic monsoon rainfall and the impacts of flooding[15,24,38]. Approximately $64 \%$ of the cultivated areas are heavily dependent on monsoon rainfall and changes in the time and duration of this monsoon rainfall could affect the agricultural production significantly, especially rice yields[10,24].

The level of vulnerability will differ across the regional setting[5]. The impacts of climate change is expected to be severe in the mountain and Himalayas as compared to plain areas[11]. In the higher altitude, population entirely rely on agriculture for their subsistence and the extreme climatic conditions will put these areas in economic stress by affecting the agricultural production and food security[11,17, $24,38]$. Table 4 shows the agricultural production affected by the water-induced disaster such as floods, landslide, inundation and land cutting.

Table 4. Cereals affected by natural disaster (in ha) [15]

\begin{tabular}{ccccc}
\hline Cereals & FY 2007 & FY 2008 & FY 2009 & FY 2010 \\
\hline Paddy & 88800 & 30873 & 92000 & 567 \\
Maize & 4271 & 549 & 1700 & 563 \\
Millet & 1451 & 3.2 & 0 & 13 \\
Total & 94522 & 31425.2 & 93700 & 1143 \\
\hline
\end{tabular}

$\mathrm{FY}=$ fiscal year

Nepal receives more than $80 \%$ of precipitation in the monsoon during June to September[17]. In most parts of the country, peasants rely on this form of precipitation for farming[30,32]. This implies that small peasants in Nepal are likely to suffer more since the poor farmers rely on rain fed cultivation for subsistence farming[10,38]. Based on the severity of the impacts, vulnerability index of climate change for Nepal is categorized as depicted in Table 5. In addition, local farmers do not have scientific knowledge about climate change and its impact on their crops[37,39,40]. Moreover, actions on climate change adaptation and mitigation are challenged by country's low financial capacity and in cooperation among the governmental sectors working on climate change[41]. There is lack of understanding between the environment ministry and ministry of forestry working in this regard[41]. Such pessimistic actions of actors working on climate change make the agricultural sector more vulnerable as compared to other livelihood options in Nepal $[9,17,41]$. 
Table 5. Nepal's districts ranking according to overall climate change vulnerability index [24]

\begin{tabular}{|c|c|}
\hline $\begin{array}{l}\text { Vulnerability } \\
\text { index }\end{array}$ & Districts \\
\hline $\begin{array}{c}\text { Very high } \\
(0.787-1.000)\end{array}$ & $\begin{array}{c}\text { Kathmandu, Ramechhap, Udayapur, Lamjung, } \\
\text { Mugu, Bhaktapur, Dolakha, Saptari, Jajarkot }\end{array}$ \\
\hline $\begin{array}{l}\text { High } \\
(0.61-0.786)\end{array}$ & $\begin{array}{c}\text { Mahottarari, Dhading, Taplejung, Siraha, Gorkha, } \\
\text { Solukhumbu, Chitwan, Okhaldhunga, Achham, } \\
\text { Manang, Dolpa, Kalikot, Khotang, Danusha, } \\
\text { Dailekh, Parsa, Salyan }\end{array}$ \\
\hline $\begin{array}{c}\text { Moderate } \\
(0.356-0.600)\end{array}$ & $\begin{array}{c}\text { Sankhuwasabha, Baglung, Sindhuli, Bhojpur, Jumla, } \\
\text { Mustang, Rolpa, Bajhang, Rukum, Rauthat, } \\
\text { Panchthar, Parbat, Dadeldhura, Sunsari, Doti, } \\
\text { Tanahu, Makawanpur, Myagdi, Humla, Bajura, } \\
\text { Baitadi, Rasuwa, Nawalparasi, Sarlahi, } \\
\text { Sindhupalchok, Darchula, Kaski } \\
\end{array}$ \\
\hline $\begin{array}{c}\text { Low } \\
(0.181-0.355)\end{array}$ & $\begin{array}{c}\text { Nuwakot, Dhankuta, Kanchanpur, Bardiya, } \\
\text { Kapilbastu, Terathum, Gulmi, Pyuthan, Surkhet, } \\
\text { Argakhachi, Morang, Dang, Lalitpur, Kailali, } \\
\text { Syanja, Kaverpalanchok }\end{array}$ \\
\hline $\begin{array}{c}\text { Very low } \\
(0.000-0.180)\end{array}$ & Ilam, Jhapa, Banke, Palpa, Rupendehi \\
\hline
\end{tabular}

Analysis and the estimation of the current visible alterations and changes which are predicted to occur in the future suggests that approximately 1.9 million populations are highly vulnerable to climate change, while 10 million populations are increasingly at risk[21,24,38]. Up to some extent, rise in the temperature can bring positive response to crop production, for example, cereals can be cultivated in higher altitude areas like Manang, Mustang[5,10]. In higher altitude, rise in temperature extend the length of the potential growing season thereby allowing earlier planting and harvesting[5]. In addition, farming in those areas can be benefitted by summer monsoon and availability of water due to snow, ice and glacial melt[3]. Moreover, consistent warming conditions support the process of natural decomposition of organic material and contribution to the nutrient uptake mechanisms[3,5,17]. However, at the same time such areas can become susceptible to natural disasters such as GLOFs that completely wash out crops along with destruction of physical infrastructures and resulting in mass casualties $[3,27]$.

However, rise in temperature can worsen the agricultural production in lower altitude (plain) where temperature is already high[5]. Consistent rise in temperature can affect both the physical and chemical properties in the soil and thus altering the yields of different crops and geographic limits may be altered by changes in soil moisture and other environmental factors[2,5]. It is expected that in drier regions, higher temperature may result in salinization and desertification of agricultural land mainly due to changes in the soil properties such as the loss of organic matter and leaching of soil nutrients[2,10]. Rise in temperature may accelerate unfavourable conditions such as developing a conduciveenvironment for weeds, insects, pests and diseases[2,5,10]. Moreover, rise in temperature will lead to increase evaporation from soil and accelerate transpiration in the plants themselves will result in moisture stress, and thus crop production will be affected significantly[2,5].
The impact of climate change is already felt in a number ways in the plain areas of Nepal; there was rain deficit in the eastern part of Terai during the year 2005/06, and the crop production reduced by $12.5 \%$ on national basis[17]. On the other hand, there was torrential rain in the mid western Terai and the crop production reduced by $30 \%$ in the year 2005/06 $[17,25]$. Mass movement and edge cutting are another impact of heavy rainfall that carry away fertile soil and deposit sediments on agricultural land[38]. Due to lack of proper irrigation facilities, agriculture production is heavily dependent on favourable weather conditions, especially during monsoon and availability of rain water, however, variation in monsoon rain highly negate the crop production in Nepal $[17,38]$. Thus, Nepal is more vulnerable to climate change with respect to its agricultural production. The ongoing alterations and changes that are likely to occur in the future will negate the water resources thereby affecting agricultural production and food security, and put poor rural agrarian communities under economic stress[3,5,11]. Extreme climatic conditions will worsen the country's agricultural sector by reducing the yield and production, reduce marginal GDP from agriculture and induce migration and civil unrest in the country[5].

\section{Adaptation to Climate Change in Nepal}

Although developed countries have organized policy and regulations to respond to extreme climatic conditions, developing countries do not have such regulations and lack adaptive capacity to tackle with it[7]. The Intergovernmental Panel on Climate Change (IPCC) 2007 defined adaptation as "adjustment in natural or human systems in response to actual or expected climatic stimuli or their effects, which moderates harm or exploits beneficial opportunities"[42]. However, adapting agriculture to climate change is equally problematic in developing countries due to lack of fiscal and technical capacity to respond to the extreme climatic events $[1,6,7,43]$. In general, adaptation options in agriculture are influenced by number of parameters such as climate, biophysical, socio-political and environmental factors[2-4, 43].

In order to respond to climate change, the government of Nepal created a National Adaptation Programme of Action (NAPA)-a multidisciplinary platform on information, data and studies on climate change to identify priority activities $[24,41]$. In 1994, Nepal signed the United Nations Framework Convention on Climate Change (UNFCCC) and also a National Climate Change Policy is in the process of elaboration[16,41]. Since the country does not have enough funds to invest on activities focused on reducing the impacts of climate change, Nepal heavily relies on donor support to cope with climate change[41]. However, the NAPA programme is not effective as expected due to lack of technical capacity and weak coordination across the government sectors, and also low awareness of climate change among the 
farmers at local levels[11,41].

Lack of funding on implementation of adaptive activities on climate change is considered as one of the bottlenecks for agriculture sector in Nepal[24,41,43]. It is estimated that the annual adaptation cost on agriculture will be in the order of US\$20,000 (about US\$70 per target household) at grassroots (village) scale in Nepal[43]. However, this amount will not be adequate in order to carry out adaptation in full scale in the country[43]. In recent years, farmers are concerned about the climatic change and are trying to adapt through technological innovations in response to climate change at their disposal[44]. Farmers have changed their cropping pattern as per the climatic adjustments and prioritized the use of organic manure rather than chemical fertilizers[39,40]. Warming and rising of temperature in the higher altitude has benefitted some households such as growing maize, and green vegetables[40]. Improved varieties of seeds are also being introduced in their farming[39, 40,44].

\section{Conclusions}

Nepal is much vulnerable to climate change. Nepal has already started to experience impacts of climate change in a number of ways, in which most critical one being the agriculture sector since more than $80 \%$ of the population heavily relies on this sector. Torrential rain, flash floods, mass movement, landslide, GLOFs are some of the major disasters occurring as a result of changing climatic patterns in Nepal, thereby affecting the agricultural production and food security in the country. The level of vulnerability will be more pronounced in higher altitude; in the mountains and hills, where majority of the people rely on subsistence farming. Despite receiving continuous financial and technical assistance from foreign donors, the process of adaptation to climate change is slow and discouraging.

\section{REFERENCES}

[1] Lybbert, T.J., and Sumner, D.A., 2012, Agricultural technologies for climate change in developing countries: Policy options for innovation and technology diffusion. Food Policy, 37(1), 114-23.

[2] Aydinalp, C., and Cresser, M.S., 2008, The effects of global climate change on agriculture. Am. Eurasian J. Agr. Envrion. Sci., 3(5),672-6.

[3] Bartlett, R., Bharati, L., Pant, D., Hosterman, H., and McCornick, P., 2010, Climate changeimpacts and adaptation in Nepal. International Water Management Institute (IWMI) Working Paper no 139, Colombo, Sri Lanka; 2010.

[4] Keane, J., Page, S., Kergna, A., and Kennan, J., 2009, Climate change and developing county agriculture: An overview of expected impacts, adaptation and mitigation challenges, and funding requirements. ICTSD-IPC Platform on climate change, agriculture and trade, Issue brief no 2, International Centre for Trade and Sustainable Development, Geneva, Switzerland and International Food \& Agricultural Trade Policy Council, Washington DC, USA; 2009.

[5] Khanal, R.C., 2009, Climate change and organic agriculture. J. Agric.Environ., 10(1),100-10.

[6] Barrios, S., Ouattara, B., and Strobl, E., 2008, The impact of climatic change on agricultural production: is it different for Africa? Food Policy, 33(4),287-98.

[7] Dulal, H.B., Brodnig, G., Thakur, H.K., and Green-Onoriose, C., 2010, Do the poor have what they need to adapt to climate change? A case study of Nepal. Local Environ., 15(7),621-35.

[8] Ellis, F., 1996, Agricultural policies in developing countries. CambridgeUniversity Press, Cambridge; 1996.

[9] Pokhrel, D.M., and Thapa, G.B., 2007, Are marketing intermediaries exploiting mountain farmers in Nepal? A study based on market price, marketing margin and income distribution analyses. Agric. Sys., 94(2),151-64.

[10] Lohani, S.N., 2007, Climate change in Nepal-shall we wait until bitter consequences? J. Agric. Environ., 8(1),38-45.

[11] Pokhrel, D.M., and Pandey, B., 2011, Climate change adaptation: strategic vision in agriculture. J. Agric. Environ., 12(1),104-12.

[12] WECS, 2002, Water resources strategy, Nepal. Water and Energy Commission Secretariat, Government of Nepal, Kathmandu, Nepal; 2002.

[13] FAO, 2002, Policy and strategy for poverty alleviation and sustainable housheold security in Nepal. Food and Agriculture Organization (FAO), Regional Office for Asia and the Pacific, Bangkok; 2002.

[14] CBS, 2002, Population Census 2001:National Report. Central Bureau of Statistics, Government of Nepal, Kathmandu, Nepal; 2002.

[15] MOF, 2011, Economic Survey: fiscal year 2010/11. Government of Nepal, Ministry of Finance, Kathmandu, Nepal; 2011.

[16] Leduc, B., Shrestha, A., and Bhattarai, B., 2008, Case study: gender and climate change in the Hindu Kush Himalayas of Nepal. International Centre for Integrated Mountain Development (ICIMOD), Gender and Climate Change Worskhop in Dakar, Senegal; 2008.

[17] Malla, G., 2008, Climate change and its impact on Nepalese agriculture. J. Agric. Environ., 9(1),62-71.

[18] Gautam, R., Baral, S., and Herat, S., 2009, Biogas as a sustainable energy source in Nepal: Present status and future challenges. Renew. Sustain. Energy Rev., 13(1),248-52.

[19] NPC, 2010, Three Year Plan Approach Paper 2010/11-2012/13. Government of Nepal, National Planning Commission, Kathmandu, Nepal; 2010.

[20] Bates, B.C., Kundzewicz, Z.W., Wu, S., and Palutikof, J.P., 2008, Climate change and water. Technical paper of the Intergovernmental Panel on Climate Change, IPCC Secretariat, Geneva; 2008.

[21] NCVST, 2009, Vulnerability through the eyes of vulnerable: climate change induced uncertainities and Nepal's 
development predicaments. Institute for Social and Environmental Transition-Nepal (ISET-N, Kathmandu) and Institute for Social and Environmental Transition (ISET, Boulder, Colorado) for Nepal Climate Vulnerability Study Team, Kathmandu, Nepal; 2009.

[22] Erikson, M., Jianchu, X., Shrestha, A.B., Vidya, R.A., Nepal, S., and Sandstrom, K., 2009, The changing Himalayasimpact of climate change on water resources and livelihoods in the Greater Himalayas. International Centre for Integrated Mountain Development, Kathmandu, Nepal; 2009.

[23] McSweeney, C., New, M., and Lizcano, G., 2008, Climate change country profiles: Nepal. United Nations Development Programme (UNDP), Kathmandu, Nepal; 2008.

[24] NAPA, 2010, National Adaptation Programme of Action (NAPA). Government of Nepal, Ministry of Environment, Kathmandu, Nepal; 2010.

[25] Regmi, H.R., 2007, Effect of unusual weather on cereal crop production and household food security. J. Agric. Environ., 8(1),20-9.

[26] Burton, I., Huq, S., Lim, B., Pilifosova, O., and Schipper, E.L., 2002, From impacts assessment to adaptation priorities: the shaping of adaptation policy. Climate Policy, 2(2-3),145-59.

[27] Karki, M., Mool, P., and Shrestha, A., 2009, Climate change and its increasing impacts in Nepal. The Initiation, 3(1),30-7.

[28] CBS, 2012, Central Bureau Statistics of Nepal. Government of Nepal, National Planning Commission Secretariat, Kathmandu, Nepal; 2012.

[29] CBS, 2011, National Population and Housing Census-2011. Government of Nepal, National Planning Commission Secretariat, Kathmandu, Nepal; 2011.

[30] NARC, 2010, NARC's strategic vision for agricultural research (2011-2030). Nepal Agricultural Research Council, Kathmandu, Nepal; 2010.

[31] MOEST/UNDP, 2008, National adaptation programme of action on cliamte change. Ministry of Environment, Science and Technology and United Nations Development Programme, Kathmandu, Nepal; 2008.

[32] Samriddhi, 2011, Commercialization of agriculture in Nepal. Samriddhi, The Prosperity Foundation, Discussion Paper, Kathmandu, Nepal; 2011.

[33] HLCSLR, 2010, High Level Commission on Scientific Land Reform 2010. Reports on suggestions to Government of
Nepal, Kathmandu, Nepal; 2010.

[34] CBS, 1993, National Sample Census of Agricultural (1991/92). Government of Nepal, Central Bureau of Statistics, Kathmandu, Nepal; 1993.

[35] DFID, 2005, Integrating indigenous and biological knowledge to implement improved dry season feeding strategies on farms in the hils of Nepal. Department of International Development London; 2005.

[36] CBS, 2003, Statistical yearbook. Government of Nepal, Central Bureau of Statistics, National Planning Commission, Kathmandu, Nepal; 2003.

[37] Wily, L.A., Chapagain, D., and Sharma, S., 2008, Land reform in Nepal: where is it coming and where is it going? The findings of a scoping study on Land Reform for DFID Nepal, Kathmandu, Nepal; 2008.

[38] Timsina, N.P., 2011, Climate change phenomenon in Nepal. NGO Federation of Nepal: A national federation of NGOs in Nepal (Presented in South Asian Climate Conference, 1-2 January 2011, organized by ANPFa and SAAPE), (accessed on 2012-01-29); 2011.

[39] Charmakar, S., 2010, Exploring existing local adaptation practices and potential strategic options to address climate change impact on biodiversity and its dependents of Nepal. National Adaptation Programme of Action/ Ministry of Environment, Government of Nepal, Kathmandu, Nepal; 2010.

[40] Manandhar, S., Schmidt, V.D., Perret, S., and Kazama, F., 2011, Adapting cropping systems to climate change in Nepal: a cross-regional study of farmers' perception and practices Reg. Environ. Change, 11(2),335-48.

[41] OXFAM, 2009, Even teh Himalayas have stopped smiling: Climate change, poverty and adaptation in Nepal. Oxfam International, Country Programme Office, Lalitpur, Nepal; 2009.

[42] IPCC, 2007, IPCC Fourth Assessment Report: Climate change 2007. Intergovernmental Panel on Climate Change, UNFCCC, New York; 2007.

[43] IIED, 2011, Costing agriculture's adaptation to climate change. Briefing, The International Institute for Environemnt and Development, London; 2011.

[44] Chapagain, B.K., Subedi, R., and Paudel, N.S., 2009, Exploring local knowledge of climate change: some reflections. J. Agric. Environ., 8(1),106-12. 